\title{
USAHA MASYARAKAT MENCEGAH KEJAHATAN
}

\author{
Oleh: Petrus Irwan Panjaitan \\ petrus.pandjaitan@yahoo.com \\ Universitas Kristen Indonesia, Jakarta, Indonesia
}

\begin{abstract}
Prevention is better than overcoming, efforts to prevent crime by relying on the potential of the community is a big advantage for the creation of effectiveness and ef ciency of crime prevention and mitigation. The rise of crimes that occur in society is a social reality that cannot be denied, crimes not only worry the government also threatens the sense of security for every member of the community. Evil arises and develops in the midst of society, it is even a product of a heterogeneous society, because it is not possible to be destroyed but can only be prevented. Efforts to prevent crime can be done through a social approach by focusing on the role of individuals and members of the community, protecting yourself by not letting go, not providing stimulation will be effective in preventing crime.
\end{abstract}

Keywords: Prevention of crime; mitigation; societ; security.

\section{Pendahuluan}

Mencegah lebih baik daripada menanggulangi. Jalan pikiran ini cukup beralasan dan relevan dengan perkembangan serta situasi sosial masyarakat Indonesia yang seclang dilanda krisis ekonomi, serta banyaknya jumlah pengangguran danterbatasiiya lapangan pekerjaan. Oleh sebab itu, usaha pencegahan kejahatan saat sekarang maupun waktu-waktu selanjutnya tidaklagi menggantungkan kepada kesiapan petugas, tetapi lebih diarahkan. pada partisipasi masyarakat.

Usaha pencegahan kejahatan dengan mengandalkan partisipasi masyarakat mendeteksi dan mengidentifikasi secara dini kejahatan yang akan terjadi merupakan keuntungan besar untuk terciptanyaefektivitas dan efisiensi pencegahan maupun penanggulangan kejahatan.

Beberapa manfaat yang diperoleh dengan partisipasi seperti ini, yaitu :

- Tidak memerlukan pola dan sistem yang rumit.

- Pengeluaran dana yang relatif sedikit/biaya murah.

- Terciptanya kerjasama diantara masyarakat dan aparat Kepolisian.

- Memupuk tanggung jawab setiap anggota masyarakat dalam rnemahami serta mengatasi masalah kejaliatan yang dapat menimpa diri sendiri, keluarga ataupun orang lain.

Bagaimana upaya masyarakat untuk mencegah kejahatan. Untuk mengetahui usaha masyarakat mencegah kejahatan.

\section{Pembahasan \\ Masyarakat dan Kejahatan}

Maraknya kejahatan yang terjadi akhir-akhir ini di berbagai daerah di Indonesia merupakan suatu kenyataan sosial yang tidak hanya mencemaskan Pemerintah sebagai lembaga yang bertanggung jawab terhadap ketertiban dan kedamaian hidup masyarakat, tapi juga mengancam rasa aman maupun aktifitas setiap anggota masyarakat.

Kejahatan tumtauh dan berkembang di tengah masyarakat, bahkan kejahatan itu merupakan produk dari masyarakat. Sehubungan dengan hal ini aliran pemikiran kriminologi kritis, berpendapat :

Bahwa fenomena kejahatan sebagai konstruksi sosial, artinya manakala masyarakat mendefinisikan 
tindakan-tindakan sebagai kejahatan, maka orangorang tertentu dan tindakan-tindakan tertentu mungkin pada waktu tertentu memenuhi batasan sebagai kejahatan. Ini berarti bahwa kejahatan dan penjahat bukanlah fenomena yang berdiri sendiri yang dapat diidentifikasi dan dipelajari secara obyektif oleh Ilmu Sosial, sebab dia ada karena hal itu dinyatakan demikian oleh "masyarakat".

Pendapat di atas, menjelaskan pada kita bahwa masyarakat dan kejahatan tidak dapat dipisahkan. Kejahatan sebagai suatu hasil interaksi antara kepentingan individu di satu piliak maupun kelompok mengakibatkan terciptanya masyarakat kelas bawah dan kelas atas dan semua ini bermuara pada kecemburuan sosial. Hal ini merangsang masyarakat yang hidup di daerah slum (kumuh), pengangguran ataupun terdorong konsumerisme untuk bertindak menyimpang dengan alasan menuntut keadilan serta pembagian secara merata dengan cara melanggar hukum. Ada kesan di masyarakat sekarang bahwa kejahatan dilakukan oleh orang-orang yang tidak berpenghasilan atau penghasilan rendah. Pernahaman ini hampir melekat pada setiap petugas maupun aparat Penegak Hukum. Padahal sebenarnya kejahatan itu banyak dilakukan oleh individu yang secara ekonomis, segi pendidikan dikategorikan mampu. Kenyataan ini semakin menggejala dan sulit dicegah.

\section{Pencegahan Kejahatan}

Pencegahan merupakan kebijakan yang cukup dapat dipertanggung jawabkan terhadap bahaya ancaman tingginya tingkat kejahatan. Hal ini sebagaimana dikatakan oleh Mardjono Reksodiputro :

Dengan bersandar pada pendapat Emile Durkheim kami berpendapat bahwa kejahatan adalah suatu gejala normal di dalam setiap masyarakat yang bercirikan heterogem'tas dan perkembangan sosial dan karena itu tidak muiigkin dimusnahkan habis. Mungkin istilah yang lebih tepat adalah "Pencegahan Kejahatan".

Menyinggung tentang pencegahan kejahatan, $\mathrm{Mu}-$ hammad Kemal Darmawan dalam bukunya Strategi Pencegahan Kejahatan ${ }^{3}$ dikenal tiga bentuk pencegahan kejahatan :

- Pencegahan kejahatan melalui pendekatan sosial,
- Pencegahan kejahatan melalui pendekatan situasional,

- Pencegahan kejahatan melalui pendekatan kemasyarakatan.

Berbagai pemikiran dan pendapat yang berkembang baik pada kalangan akademisi maupun praktisi selalu menghendaki kebijakan pencegahan kejahatan melalui pendekatan kemasyarakatan, hal ini dapat kita lihat di Indonesia seperti adanya siskamling (Sistem Keamanan Lingkungan). Bentuk ini dianggap lebih praktis dan tidak memerlukan sarana yang banyak. Masalahnya adalah perlu ada kejelasan di masyarakat untuk konsisten mempertahankan pola tersebut. Pencegahan kejahatan itu sendiri dapat diusahakan melalui beberapa hal, seperti :

- Mempersiapkan petugas profesional di setiap wilayah (pemukiman/tempat tinggal) masyarakat secara efektif dan efisien;

- Memberikan penerangan di sekitar wilayah rawan ancaman kejahatan;

- Membentuk kelompok-kelompok dalam masyarakat untuk meiigorganisasikan kegiatankegiatan sosial yang berdampak terhadap keamanan lingkungan;

- Menghargai prestasi-prestasi warga masyarakat yang mempunyai minat terhadap lingkungan;

Memasyarakatkanperaturan perundang-undangan yang menjadikan setiap anggota masyarakat punya tangguiig jawab mencegah kejahatan, seperti UU No. 8 tahun 1981 teiitang Hukum Acara Pidana, dimana dalam pasal 108 dan pasal 109, jelas-jelas mewajibkan masyarakat untuk mencegah danmenanggularigi kejahatan.

Pencegahan kejahatan dengan menitik beratkan keikut sertaan masyarakat, mengharuskan perlunya koordinasi dari pihak-pihak yang bertanggung jawab, dengan mekanisme kerja yaitu : pemantauan, modus operandi dan evaluasi. Hal ini dapat diinformasikan kepada setiap anggota masyarakat yang hendak berpergian meninggalkan rumah. Oleh karena itu, sebagai konsekuensinya harus ada Pxisat Informasi Kejahatan (PIK) yang bertujuan untxik mengetahui pelaku beserta ciri-cirinya serta modus operandi. 


\section{Peran Serta Masyarakat}

Menyinggung peneegahan kejahatan dengan rnasyarakat sebagai partisipan, ten tuny a bukan hal baru dan asing bagi rnasyarakat yang rnemang mengerti bahaya kejahatan. Tetapi seringkali dilupakan apa arti dan peran individu dalam pencegahan kejahatan. Masyarakat yang menurut pemahaman sosiologis merupakan kumpulan/himpunan dart individu dan mempunyai tujuan dan kepentingan sosial. Hal ini berarti baliwa individu merupakan titik utama dalam peneegahan kejahatan.

Secara lebih rinci dapat digambarkan sebagai berikut : Melindungi diri sendiri dengan tidak rnelakukaan pembiaran (permissiveness), tidak memberikan rangsangan dengan cara mempertontoiikan barangbarang berharga akan efektif untuk mencegah daii sasaran pelaku. Interaksi antara pelaku dan korban serta rnasyarakat merupakan suatu bingkai yang tidak dapat dipisahkan begitu saja dari kondisi sosial rnasyarakat yang rawan kejahatan. Masyarakat sudah saatnya mengembangkan pelayanan individu kepada sesama manusia yang tidak mampxi dalam mencvikupi kebutuhan sosial ekonominya. Pemenuhan kebutuhan sehari-hari dari anggota rnasyarakat merupakan hal yang mendasar mengingat baliwa kesulitan ekonomi bisa mengancam rnasyarakat dan dapat berakibat disharmoni dan bermuara pada terciptanya kejahatan. Sehubungan dengan hai ini, maka partisipasi rnasyarakat tidak dapat ditawar-tawar lagi, sebagaimana dikatakan Mardjono Reksodiputro.

Indonesia menyatakan bahwa program pembangunan nasional telah menegaskan pentingnya usahausah.a peneegahan kejahatan, oleh karena diakui bahwa peningkatan kejahatan tidak saja merintangi kegiatan pembangunan tetapi tercapainya stabilitas nasional dan masyarakat adil dan makmur. Peneegahan kejahatan ini mencakup berbagai kegiatan dan program yang dapat dilakukan oleh badan-badan pemerintah, badan-badan swasta, kelompok masyarakat setempat, keluarga dan masyarakat pada umumnya.

Pencegahan kejahatan, sulit berhasil hanya dengan mengandalkan kemampuan aparat keamanan, upaya mengikut sertakan individu anggota rnasyarakat dengan mempertimbangkan aspek-aspek sosial budaya. Menyinggung peranan individvi dengan tidak membi- arkan dirinya menjadi pelaku maupun korban kejahatan, diperlukan konsep yang jelas tentang apa itu peran individu. Individvi sebagai bagian dari masyarakat yang berbudaya, tidak hanya menuntut agar diperlakukan adil, tapi harus menjadi anggota masyarakat yang sadar akan hukum dan kewajibannya dengan meningkatkan solidaritas diantara sesama. Solidaritas kelompok dalam mencegah kejahatan bukan sekedar memerangi pelaku semata tetapi membina korban maupun keluarga serta bekas pelaku. Pembinaan terhadap keluarga korban tujuannyauntuk mencegah agar jangan melakukan pembalasan terhadap pelaku maupun keluarganya.

Oleh sebab itu, dapat disimpulkan bahwa pencegahan kejahatan dengan partisipasi masyarakat dapat berbentuk sebagai berikut :

- Individu sebagai anggota masyarakat tidak melakukan menyebabkan orang terpancing melakukan kejahatan;

- Tidak membiarkan diri sendiri menjadi sasaran kejahatan;

- Menjaga dan mengamankan wilayah pemukiman;

- Membantu masyarakat yang sosial ekonominya lemah;

- Melindungi individu yang lemah mental, fisik serta sosialnya;

- Tidak mempertontonkan kekayaan;

- Bekerjasama dengan pihak polisi;

- Menjaga lingkungan sosial agar tetap harmonis.

Kejahatan lebih baik di cegah dari pada di tanggulangi, khususnya melalui peran individu anggota masyarakat. Alasannya, karena mencegah itu tidak memerlukan biaya yang banyak, tidak memerlukan sistem yang rumit. Adapun manfaat yang diperoleh dari mencegah kejahatan, yaitu : memupuk rasa tanggung jawab setiap individu warga negara terhadap ketertiban dan keamanan lingkungan, mendekatkan anggota masyarakat dengan pihak kepolisian melalui saling bertukar informasi mengenai ketertiban dan gangguan kejahatan.

Secara sosial kejahatan dapat di kelompokkan dalam (1) White Collar Crime, (2) Organized Crime. (2) Victimless Crime dan (4) Conventional Crime. 
Kejahatan yang di maksud dalam tulisan ini adalah, kejahatan konvensional (Conventional Crime). Masih sumber yang sama mengatakan bahwa conventional crime sebagai sebuah social concept of crime dapat dikelompokkan kepada dua kategori sosial kejahatan yaitu : (1) Crime of Violence, yang secara legal terdiri dari : pembunuhan,perkosaan, perampokan penodongan dan (2) Property Crimes seperti : pencurian, pencurian kendaraa motor, vandalisme, pembakaran rumah dengan sengaja dan penipuan.. W.A Bonger menyatakan kejahatan adalah perbuatan yang sangat anti sosial yang memperoleh tentangan dengan sadar dari Negara berupa pemberian penderitaan (hukuman atau tindakan)

\section{Kerugian Akibat Kejahatan}

Sebagai masalah sosial, Kejahatan tampaknya tidak hanya merupakan masalah bagi suatu masyarakat tertentu, tetapi juga menjadi masalah yang dihadapi sejumlah masyarakat di dunia, serta menimbulkan kerugian. Sebagaimana hasil kongres PBB ke lima tahun 1975 menyatakan biaya kejahatan yang tersembunyi lebih besar dari pada biaya kejahatan yang diketahui. Biaya kejahatan itu di ukur atau di hitung dari segi :

- Kerugian-kerugian itu terhadap individu dan masyarakat;

- Biaya-biaya atau pengeluaran-pengeluaran masyarakat untuk melakukan pencegahan dan pengendalian kejahatan dan

- Kegelisahan-kegelisahan yang timbul di masyarakat segubungan dengan meratanya dan meningkatnya kejahatan-kejahatan kekerasan dan kejahatan-kejahatan terhadap harta benda.

Berkaitan dengan itu juga, Topo Santoso mengatakan: Kejahatan juga menimbulkan kerugian tidak langsung, biaya itu dikeluarkan dalam menyelenggarakan sistem peradilan pidana yang harus memproses tersangka atau terdakwa. Banyak biaya harus dikeluarkan untuk Polisi, Jaksa, Pengadilan maupun lembaga pemasyarakatan. Lebih lanjut dikatakannya: Tidak semua ongkos tak langsung dari kejahatan berkaitan dengan sistem peradilan pidana karena ada pula biaya yang berkaitan dengan perubahan sikap dan perilaku masyarkat yang sebenarnya tidak pernah mengalami kejahatan itu sendiri. Mereka harus mengeluarkan ban- yak uang untuk pencegahan agar tidak menjadi korban kejahatan. Mereka harus memasang alarm serta pintu dam jendela khusus, membayar penjaga keamanan, mengurangi bisnis di malam hari, dan sebagainya yang jika dihitung jumlahnya sangat besar.

Kejahatan tumbuh dan berkembang di tengah masyarakat, bahkan kejahatan itu merupakan produk dari masyarakat. Sebagaimana aliran pemikiran kriminologi kritis, berpendapat:

Bahwa fenomena kejahatan sebagai konstruksi sosial, artinya manakala masyarakat mendefinisikan tindakan-tindakan sebagai kejahatan, maka orangorang tertentu dan tindakan-tindakan tertentu mungkin pada waktu tertentu memenuhi batasan sebagai kejahatan. Ini berarti bahwa kejahatan dan penjahat bukanlah fenomena yang berdiri sendiri yang dapat diidentifikasi dan dipelajari secara obyektif oleh Ilmu Sosial, sebab dia ada karena hal itu dinyatakan demikian oleh "masyarakat".

Dengan demikian masyarakat dan kejahatan tidak dapat dipisahkan. Dimana ada masyarakat disitu pasti ada kejahatan, hal ini menggambarkan bahwa bilamana terdapat interaksi sosial serta kebutuhan sosial ekonomi maka hal itu dapat menjadi salah satu pemicu perilaku jahat. Disamping itu, dimasyarakat dibangun suatu struktur masyarakat kelas bawah atau kelas tidak berpunya dan kelas berpunya yang sebetulnya menjadi pemicu juga untuk timbulnya kecemburuan sosial.

\section{Pencegahan Kejahatan}

Pencegahan kejahatan itu mutlak dan perlu di lakukan mengingat bahaya ancaman tingginya angka kejahatan. Hal ini sebagaimana dikatakan oleh Mardjono Reskodiputro :

Dengan bersandar pada pendapat Emile Durkheim, kami berpendapat bahwa kejahatan adalah suatu gejala normal di dalam setiap masyarakat yang bercirikan heterogensitas dan perkembangan sosial dan karena itu tidak mungkin dimushankan habis. Mungkin istilah yang lebih tepat adalah "Pencegahan Kejahatan".

Menyinggung tentang pencegahan kejahatan, $\mathrm{Mu}-$ hammad Kemal Darmawan dalam bukunya Strategi Pencegahan Kejahatan dikenal tiga bentuk pencegahan kejahatan : 
- Pencegahan kejahatan melalui pendekatan sosial,

- Pencegahan kejahatan melalui pendekatan situasional,

- Pencegahan kejahatan melalui pendekatan kemasyarakatan

Dengan demikian, mencegah kejahatan melalui pendekatan kemasyarakatan lebih efektif, salah satunya adalah meningkatkan partisipasi masyarakat. Di Indonesia pernah mengenal partisipasi masyarakat untuk mencegah kejahatan, melalui sistem keamanan lingungan. Sistem ini dianggap cukup efektif mengingat adanya kegiatan "ronda" atau jaga malam, di mana masing-masing anggota rumah tangga secara bergilir pada setiap malam hari melakukan kegiatan menjaga lingkungan masing-masing.

Dalam hal ini, sistem keamanan lingkungan yang ada di setiap pemukiman biasanya melibatkan petugas profesional, terlebih di wilayah rawan kejahatan dan memberikan penerangan dan himbauan kepada masyarakat untuk mengorganisasikan kegiatan-kegiatan sosial yang berdampak pada tanggung jawab terhadap lingkungan. Disamping itu juga memasyarakatkan peraturan perundang-undangan yang mewajibkan setiap warga negara memliki tugas mencegah kejahatan seperti yang diatur didalam undang-undang RJ No. 8 Tahun 1981 Tentang Hukum Acara Pidana, dimana di Pasal 108 dan Pasal 109, dinyatakan adanya kewajiban masyarakat untuk mencegah dan menanggulangi kejahatan.

Pencegahan kejahatan dengan melibatkan peran anggota masyarakat mengharuskan perlu ada kordinasi dengan pihak kepolisian serta pembagian tugas, seperti menginformasikan modus-modus kejahatan serta melakukan evaluasi.

\section{Peran Serta Pemuda Gereja Mencegah Keja- hatan.}

Pencegahan kejahatan dengan pemuda gereja sebagai partisipan, bukan hal bam dan asing bagi masyarakat. Namun belakangan ini dilupakan apa arti dan peran individu dalam pencegahan kejahatan. Masyarakat secara sosiologis merupakan himpunan dari individu dan mempunyai tujuan sosial yang berbeda-beda. Hal ini berarti bahwa individu merupakan titik utama dalam menyelesaikan masalah yang timbul, khususnya pencegahan kejahatan.

Pencegahan kejahatan, dapat dilakukan melalui: Melindungi diri sendiri dengan tidak melakukan pembiaran (Permissiveness), tidak memberikan rangsangan dengan cara mempertontonkan barang-barang berharga. Bilamana hal ini dilakukan maka akan terjadi interaksi dengan pelaku kejahatan. Interaksi pelaku kejahatan dan anggota masyarakat tidak dapat dipisahkan begitu saja dari kondisi sosial ekonomi masyarakat yang masih banyak tidak mampu mencukupi kebutuhan hidupnya sehari-hari. Sehubungan dengan hal ini, maka partisipasi masyarakat tidak dapat ditawar-tawar lagi, sebagaimana dikatakan Mardjono Reksodiputro.

Indonesia menyatakan bahwa program pembangunan nasional telahmenegaskan pentingnya usaha-usaha pencegahan kejahatan, oleh karenadiakui bahwa peningkatan kejahatan tidak saja me- rintangi kegiatanpembangunan tetapi tercapainya stabilitas nasional dan masyarakat adil danmakmur. Pencegahan kejahatan ini mencakup berbagai kegiatan dan programyang dapat dilakukan oleh badanbadan pemerintah, badan-badan swasta,kelompok masyarakat setempat keluarga dan masyarakat pada umumnya.

Pencegahan kejahatan, sulitberhasil hanya dengan mengandalkan kemampuanaparat keamanan, upaya mengikut sertakan individu anggota masyarakat denganmempertimbangkan aspek-aspek sosial budaya. Menyinggung peran pemuda gerejadalam pencegahan kejahatan adalah dengan tidak membiarkan dirinya menjadi pelakumaupun korban kejahatan. Mengapa demikian karena pemuda itu adalah bagian darimasyarakat yang berbudaya, dimana tidak hanya menuntut agar diperlukan adil, tapihams menjadi anggota masyarakat yang sadar akan hukum dan kewajibannya denganmeningkatkan solidaritas diantara sesama. Oleh sebab itu peran serta pemuda gereja dalam pencegahan kejahatan dapat dilakukan melalui : a) Tidak melakukan provokasi yang menyebabkan orang terpancing melakukan kejahatan, khususnya kepada wanita dengan tidak bepergian seorang diri pada saat dan di tempat-tempat tertentu; b) memberikan bantuan kepada anggota masyarakat yang secara sosial 
ekonominya lemah;c) Ikut menjaga serta memelihara keamanan lingkungan ; d) Memelihara hubungan sosial agar tetap harmonis; e) Tidak memprovokasi orang lain melalui mempertontonkan kekayaan yang dimiliki; f) Memberi bantuan kepada individu anggota masyarakat yang lemah mental, fisik serta sosialnya ; g) Menghubungi pihak kepolisian bila ada ancaman kejahatan.

\section{Kesimpulan dan Saran}

Mencegah lebih baik dari pada menanggulangi, hal ini bukan sesuatu yang muluk-muluk. Sebab setiap orang dapat melakukannya, tanpa harus memerlukan biaya dan cara-cara yang rumit. Namun orang ser- ing menganggap bahwa mencegah kejahatan bukan merupakan kewajibannya. Pandangan demikian ada- lah keliru karena pribadi atau individu yang sangat mengetahui, apakah dia berada dalam keadaan teran- cam, memprovokasi orang lain atau tidak. Oleh sebab itu, setiap individu dapat merekah-rekah apakah dia merasa aman atau tidak bila berada atau bermukim di suatu tempat. Rasa aman dan tentram setiap individu ang- gota masyarakat, dapat dirasakan dan diperoleh bila mau ikut berperan serta untuk mencegah kejahatan. 


\section{DAFTAR PUSTAKA}

Johanes Sutoyo, Kejahatan dan Korban Kejahatan, Makalah Siposium Nasional Mengenai Pencegahan Terjadinya Korban, Jakarta, 18 Juli 1994.

W.A. Bonger, Pengantar Tentang Kriminologi, Jakarta

: Djambatan, 1982.

Barda Nawawi Arif, Kebijakan Legislatf dalam Pen- anggulangan Kejahatan dengan PidanaPenjara, Semarang : Ananta, 1994.

Topo Santoso, Polisi dan Jaksa Keterpaduan atau Pergulatan, Depok : Pusat Studi Sistem Peradilan Pidana Indonesia (Centre For Indonesian Kriminal Justice Studies). 2000,

I.S Susanto, Aliran Pemikiran Dalam Kriminologi Dan Pengaruhnya Terhadap Orientasi Studi Kejahatan, Makalah, Penataran Nasional Hukum Pidana dan Kriminologi Untuk Dosen Fakultas Hukum Per- guruan Tinggi Negeri/Perguruan Tinggi Swasta se Indonesia, 12-13 Juni 1993

Mardjono Rekosdiputro, Kriminologi dan Sistem Peradilan Pidana, Kumpulan Karangan, Buku Kedua, Jakarta : Pusat Pelayanan Keadilan dan Pengabdian Hukum (d/n Lembaga Kriminologi) UI, 1994.

Muhammad Kemal Darmawan, Strategi Pencegahan Kejahatan, Bandung: Citra AdityaBakti, 1994. Mardjono Rekosdiputro, Bunga Rampai Permasala- han Dalam Sistem Peradilan Pidana, Kumpulan Karangan ilmiah, Jakarta, Pusat Pelayanan dan Pengabdian Hukum (d/h), Lembaga Kriminologi UI, 1997. 